\title{
A Potential Study of HUA-IT Market Aiming as a Collection and Distribution Center of Agricultural Products in Southern of Thailand
}

\author{
Sakesun Suthummanon ${ }^{1}$, Pallapat Penjamras ${ }^{1}$, Somboon Jaroenjiratrakul ${ }^{1}$, \\ Sopin Suddsa-oad ${ }^{2}$ and Nikorn Sirivongpaisal ${ }^{1}$ \\ ${ }^{1}$ Prince of Songkla University, \\ ${ }^{2}$ Southern of College Technology \\ Thailand
}

\section{Introduction}

Due to shrinkage of economic situation of the South, government and private agencies has collaborated to solve the problem that focused on productivity improvement in the agricultural sector in order to aid farmers, who are main proportion of people in Thailand. The sector that was directly involved in this mission is the agricultural central market. It, which is a governmental agency, has a role to support farmers and buyers in providing a place where agricultural products can be traded according to standards of quality and price. Agricultural central market has vital roles such creating opportunities for marketing activities, increasing efficiency or decreasing logistics costs of agricultural products, minimizing losses and risks from collecting and distributing products, and strengthening the standards of Thai agricultural products. Market System Promotion and Development Division, which is under Department of Internal Trade, Ministry of Commerce has authority and responsibility in supporting private sector to establish and manage central market under the support of province and the department. There are three categories of the central market in Thailand, which are paddy and crops central market, fruit and vegetable central market, and marine central market; which are located nationwide, totally 76 markets under promotion. Especially, fruit and vegetable markets are located in the North 7 markets, in the Northwest 4 markets, in the Central 5 markets, and in the South 4 markets.

Business process along the supply chain of central market starts from harvesting and collecting agricultural products from farms, and transporting to central market, which may be intermediary market or distribution market. And from central market, products are distributed to destinations, where depending on types of consumers, which may be domestic or international. Each market has the same common problems such preservation after post-harvest, cold storage, packaging, inefficient transportation, ineffective distribution, etc. In order to strengthen the mission of central market, continual improvement is absolutely inevitable. Such in this research, it was focused on fruit and vegetable central market, named Hua-It Market, located in Nakon Si Thammarat Province, as shown in Figure 1 below. Hua-It Market has an important role in helping to produce jobs 
and incomes for the populace of Nakon Si Thammarat, and other provinces in the South. Therefore Department of Internal Trade Office of Nakon Si Thammarat desired to remodel Hua-it Market into a collection and distribution center of agricultural products in the southern Thailand in order to strengthen the regional economy.

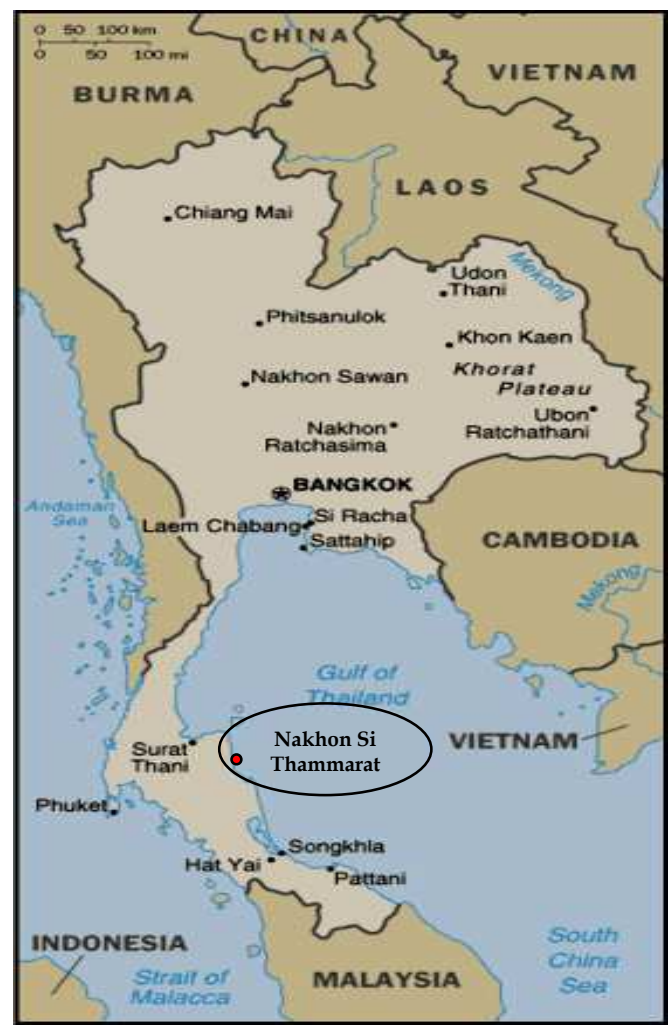

Fig. 1. Geographic Location of Hua-It Market, Nakhon Si Thammarat (Source: http://en.wikipedia.org/wiki/File:Thailand_map_CIA.png)

Key functions assigned to Hua-It Market as a collection and distribution center are such (1) being a center for the classification of agricultural products, serving as product quality grading, packaging, storage, product quality preserving, testing for plant diseases and insects, testing for contaminants and toxic residues, or in Thailand can be called as "Agricultural Quality Grading Center (AGQC)", (2) promoting collaboration among members for trading in Hua-It Market, (3) supporting an export to Singapore, Malaysia, Indonesia, and Middle East, and (4) reducing the logistics costs along Hua-It supply chain. To achieve the mission, two questions came up in the following.

The first question in this research, "whether or not, Hua-It Market has potential enough to be a collection and distribution center for the southern Thailand, along the requirements of Office of Internal Trade, Nakhon Si Thammarat". Becoming as a center for collecting and distributing agricultural products of the southern Thailand, it depends on various factors. 
All these factors are affecting the costs incurred in collecting and distributing agricultural products from upstream to downstream, thus the studies to assess the potential of Hua-It Market to be as a collection and distribution center for the southern Thailand are crucial from the perspective of the logistics and supply chain management.

And the second question in the study, which is successive from the first question, "To aim to be the collection and distribution center of agricultural products for the southern Thailand, what are the strategies for Hua-It Market?" Consequently, in this research will focus on formulating strategies in order to propose to Department of Internal Trade Office of Nakhon Si Thammarat. These strategies will be assessed from the viewpoint of logistics and supply chain management, resulting from analysis of Hua-It's potential.

Therefore, this research was studied to analyze the potential of Hua-It Market aiming towards to be a collection and distribution center for the southern Thailand. Analysis framework was made under the concept of logistics and supply chain management, which aimed to study the relationships of each logistics activities along the Hua-It supply chain and costs incurred in each process of the supply chain. Data collected from area-based were applied in developing supply chain models for the sake of analyzing the potential of the supply chain, which can help to profoundly comprehend the processes and characteristics of Hua-It Market, and strategy analysis of Hua-It Market as a collection and distribution center. The contribution of research results can be the prototype for other fruit and vegetables central markets under promotion of Department of Internal Trade, which aim to improve their status. Furthermore, the formulated strategies in this research also may be valuable, and the developed models in this research can clearly convey the thoughts, which have linkage with Hua-It strategies. Finally, it represents the applicability of operation research technique to the real world problem.

As previously mentioned the problem statements, objectives of research can be stated as four main thrusts: (1) to study and survey logistics and supply chain system of Hua-It Market, also including with infrastructures, goods inflow and outflow, numbers of farmers and customers involved in supply chain, routes of incoming and outgoing goods; (2) to develop supply chain models of Hua-It Market; (3) to study and assess potential of Hua-It Market aiming to be a collection and distribution center of agricultural product in southern of Thailand and nearby countries, which are Singapore, Malaysia, Indonesia, and Middle East; (4) to formulate strategies for Hua-It Market in fitting itself to be a collection and distribution center, and propose to Nakon Si Thammarat Province and Department of Internal Trade Office of Nakon Si Thammarat.

\section{Literatures review}

Campbell presented hub location problems, which have important applications in transportation systems. He proposed integer programming formulations for four types of discrete hub locations problem, which are analogous to four fundamental types of discrete facility location problems. These hub problems are the $p$-hub median problem, the uncapacitated hub location problem, the $p$-hub center problems, and the hub covering problems. (Campbell, 1994)

Beamon studied supply chain design and analysis, focusing on models and methods. This work intends to review the past research works in the field of supply chain modeling and to 
propose the future work in this field. The study summarized that supply chain is a collection of business processes under various stakeholders, including suppliers, manufacturers, distributors, and retailers. In supply chain, there are two fundamental activities (1) production planning and inventory control arising in the upstream of supply chain, (2) distribution and logistics processes occurring in the downstream. And supply chain model can be classified as (1) deterministic analytical models, (2) stochastic analytical models, (3) economic models, and (4) simulation models. The decision variables related to supply chain models also differentiate to various kinds such as production patterns, production schedules, inventory levels, distribution channels, etc. (Beamon, 1998)

Lertkrai studied the structure and the dynamic of Hua-It Market, Nakhon Si Thammarat, under the field of economic anthropology based on the concept of the social dynamic, the concept of dialectic, and theory of culture. The study began by reviewing the documents, and field surveying. It was found out that originally Hua-it was just the place for bus stopping before entering the city. But in these buses there were loading up of vegetables so the merchants just came to buy these products for selling. Later, Mr. Suporn Intharavichian prepared his own land and founded as a market for trading among sellers and buyers. And this market gradually grew up since then. (Lertkrai, 2000)

Fernie and Staines studied an understanding of European grocery supply chain. This research is survey oriented in order to acquire data and use them as input for planning supply chain management of grocery products in the future. The study started from downstream of supply chain or retailers, and tracing back to manufacturers. The studied variables were categorized into three groups, namely trading structure, physical characteristics, economic and social structures, totally eighteen variables. The surveyed samples were (1) consumers in 10 countries in Europe; (2) major retailers in Europe, including Metro, Rewe, Tengelmann, Aldi, Carrefour, etc; (3) major manufacturers such as Unilever, Nestle, Philip Morris, Heineken, etc. From the study, they found out that the trading between supply chain members through computer system help in cost reduction and facilitating partnerships among supply chain. (Fernie and Staines, 2001)

Poorpongsakorn studied an analysis management system of fresh fruits and processed fruits in the east of Thailand in order to obtain the approach in organizing and managing the market and distribution system. The objectives of this study are (1) to study trend and future consumption, export, and production of these three fruits, which are durian, mangosteen, and rambutan, (2) to analyze trend of price and volatility in price of fruits, (3) to survey and assess the fruit market system and marketing margin, etc. In this study, it was found out that the main problem of production and marketing system of fruits affecting the income of farmers and exporters was that the price of products had been decreased or remained stable while production costs had been increased. Therefore strategic management of fresh fruits and processed fruits in the east should focus on the farmers and the exporters such quality improvement of marketing management system or development of production system and modern marketing system focusing on fruits value added. (Poorpongsakorn, 2005)

Cochran and Ramanujam conducted a research about carrier mode logistics optimization of inbound supply chain for electronics industry. The problem statement is about that physical flow and information flow from manufacturer to factory experienced with problem in the 
relatively high cost. Thus it outsourced third party logistics provider to operate the transportation activity. By selecting the carrier was very complicated, thus the indicator that helped the company in making a decision was the total cost reduction. Factors affected the cost influencing in selecting third party logistics providers were packaging sizes, packaging styles, etc. In this research proposed the method of selection third party logistics providers based on numerical programming. (Cochran and Ramanujam, 2006)

Campo and Beghin studied dairy food consumption, supply, and policy in Japan. The study surveyed and interviewed Japanese entrepreneur, also studied the secondary data obtained from the economic history of Japan. Demands of dairy products in the past were used to forecast the current and future demands of products. The study found out that dairy market has received attention since after World War II. And the factors that affected consumer demand were the economy, society, and culture, including consumer needs. (Campo and Beghin, 2006)

\section{Research methodology}

The concept underlying in this study is gap analysis. Between Hua-It Market and reference site, which is a market where is considered as best practice of a collection and distribution center, performance indicators were compared. In addition, these indicators were developed and analyzed from the viewpoint of logistics and supply chain management. Since market is the place where facilitates the trading between vendors and buyers and market system is a system comprising of many components which are interrelated in nature. Thus examining such system like market from viewpoint of logistics and supply chain concept, it will be very helpful. In conducting research, the methodology can be represented in the following stages.

\subsection{Preliminary survey of background information of Hua-It and reference site}

In this stage, a preliminary survey of current status of Hua-It Market was made in order to develop performance indicators and to use as guideline for designing the questionnaire. From preliminary survey data, such information were applied for the development of various indicators related to the points in this study such being a center for the classification of agricultural products, collaboration among members for trading in Hua-It Market, logistics costs, etc. The questionnaire developed is divided in three parts as follows (1) general inquiries, (2) performance indicators of market, and (3) opinion and suggestion. Furthermore, the questionnaire was tested for validity and reliability before it was exercised.

\subsection{Field data collection of Hua-It and reference site}

In this step the following data were collected from fields, which are Hua-It Market and reference site: (1) demand, (2) supply, (3) inbound and outbound physical flows, (4) infrastructures, (5) routes from origin to destination, and (6) logistics costs. The questionnaire developed in 3.1 is a main tool used in field data collection. And sampling method applied was a stratified random sampling and in each stratum, simple random sampling was used. Besides questionnaire, deep interview was applied to. 


\subsection{Gap analysis between Hua-It and reference site}

A study of "AS-IS" status of Hua-It market and "TO-BE" status of a collection and distribution center, which is considered from a reference site market that has best practices, was made in this step. From previous data collection, an analysis was made in this stage in order to investigate the discrepancy between Hua-It and reference site. Or it can be said that the analysis aims to justify the "AS-IS" status of Hua-It Market and the "TO-BE" status of reference market. And observation of the variation between Hua-It and reference site was made. The result from this investigation is gap, which will be used as input in the next stage.

\subsection{Strategies formulation}

After the gaps between Hua-It Market and reference market was indicated, the challenge is how these gaps can be reduced or eliminated. To fulfil such question, strategies are compulsory for Hua-It Market in aiming toward a collection and distribution center. Thus strategy formulation is the mission in this stage.

\begin{tabular}{|c|c|c|c|c|}
\hline Internal Factors & $\begin{array}{l}\text { Weight } \\
\text { (1) }\end{array}$ & $\begin{array}{l}\text { Rating } \\
(2)\end{array}$ & $\begin{array}{c}\text { Weighted Score } \\
(3)=(1) *(2)\end{array}$ & Comments \\
\hline \multicolumn{5}{|l|}{ Strengthes } \\
\hline S1.................. & 0.15 & 5.00 & 0.75 & \\
\hline S2................ & 0.05 & 3.00 & 0.15 & \\
\hline S3.................. & $\ldots . .$. & $\ldots . .$. & $\ldots . .$. & \\
\hline 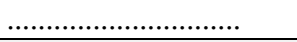 & $\ldots \ldots$ & $\ldots \ldots$ & $\ldots \ldots$ & \\
\hline \multicolumn{5}{|l|}{ Weaknesses } \\
\hline$W 1 \ldots \ldots \ldots \ldots \ldots \ldots$ & ....... & $\ldots \ldots$ & ....... & \\
\hline W2 ................... & $\ldots \ldots$. & $\ldots \ldots$. & ....... & \\
\hline 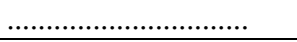 & $\ldots \ldots$. & ....... & $\ldots \ldots$. & \\
\hline Total & 1.00 & & & \\
\hline External Factors & $\begin{array}{l}\text { Weight } \\
\text { (1) }\end{array}$ & $\begin{array}{l}\text { Rating } \\
(2)\end{array}$ & $\begin{array}{c}\text { Weighted Score } \\
(3)=(1)^{*}(2)\end{array}$ & Comments \\
\hline \multicolumn{5}{|l|}{ Opportunities } \\
\hline $\mathrm{O} 1 \ldots \ldots \ldots \ldots \ldots \ldots$ & 0.10 & 3.00 & 0.30 & \\
\hline $\mathrm{O} 2 \ldots \ldots \ldots \ldots \ldots \ldots$ & 0.03 & 4.00 & 0.12 & \\
\hline …............................... & $\ldots . .$. & $\ldots \ldots$ & $\ldots . .$. & \\
\hline \multicolumn{5}{|l|}{ Threats } \\
\hline T1................ & $\ldots \ldots$. & $\ldots \ldots$. & ....... & \\
\hline $\mathrm{T} 2 \ldots \ldots \ldots \ldots \ldots$ & $\ldots \ldots$. & $\ldots \ldots$. & $\ldots \ldots$. & \\
\hline 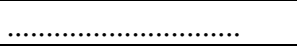 & $\ldots \ldots$ & $\ldots \ldots$ & $\ldots \ldots$ & \\
\hline Total & 1.00 & & & \\
\hline
\end{tabular}

Table 1. Calculation of Weighted Scores

Stages of formulating strategy can be concisely explained as follows. (1) Analyze the strengths (S), weaknesses (W), opportunities (O), and threats (T) of Hua-It Market by using data from field survey with questionnaire, from brainstorming among all those stakeholders of Hua-It, and from Nakhon Si Thammarat Province's strategy. Both strengths and 
weaknesses are considered as internal factors, while opportunities and threats are deemed as external factors. (2) Prioritize S, W, O, T, by using Likert's Scale 1-5, which 1 is the least important and 5 is the most important. And evaluate the weight given to each $\mathrm{S}, \mathrm{W}, \mathrm{O}$, and $\mathrm{T}$, which the minimum weight is 0.0 and the maximum weight is 1.0. The weight of internal factors, which are $\mathrm{S}$ and $\mathrm{W}$, is equal to 1.0, the weight of external factors, which are $\mathrm{O}$ and $\mathrm{T}$, is equal to 1.0, as well. Then multiply priority rating with the weight given, the result is weighted score of each factor. This step can be shown in Table 1. (3) Select S, W, O, and T with the highest weighted score which are accounted for eighty percent of all the factors to match up in term of the matrix. This is commonly known as TOWS Matrix Diagram in order to determine the strategies. An example of TOWS Matrix Diagram can be shown in Table 2 below. From this diagram, the strategy can be seen from different perspectives. (4) Summarize the obtained strategies from previous step, and then unite the similar strategies as one.

\begin{tabular}{|c|c|c|}
\hline External Factors & $\begin{array}{c}\text { Strengthes } \\
\text { S1................ } \\
\text { S2............... } \\
\text { S3.............. }\end{array}$ & $\begin{array}{l}\text { Weaknesses } \\
W 1 \ldots \ldots \ldots \ldots \ldots . . . \\
W 2 \ldots \ldots \ldots \ldots \ldots . \\
W 3 \ldots \ldots \ldots \ldots \ldots\end{array}$ \\
\hline \multicolumn{3}{|l|}{ Opportunities } \\
\hline $\mathrm{O} 1 \ldots \ldots \ldots \ldots \ldots$ & $\mathrm{SO} 1 \ldots \ldots \ldots \ldots . . . . . .$. & WO1............... \\
\hline $\mathrm{O} 2 \ldots \ldots \ldots \ldots \ldots$ & $\mathrm{SO} 2 \ldots \ldots \ldots \ldots \ldots$ & WO2 $\ldots \ldots \ldots \ldots \ldots$ \\
\hline $\mathrm{O} 3 \ldots \ldots \ldots \ldots \ldots$ & SO3............... & WO3............... \\
\hline \multicolumn{3}{|l|}{ Threats } \\
\hline T1............... & ST1............... & WT1 ............... \\
\hline $\mathrm{T} 2 \ldots \ldots \ldots \ldots \ldots$ & ST2............... & WT2 $2 \ldots \ldots \ldots \ldots \ldots$ \\
\hline T3............. & ST3............. & WT3............... \\
\hline
\end{tabular}

Table 2. TOWS Matrix Diagram

\subsection{Supply chain models development}

When the strategies for Hua-It Market were formulated, conveying the idea behind the strategies, which is abstract, to concrete is indispensable. There are numerous ways to achieve this requirement. In this research, quantitative modeling was selected. These developed supply chain models demonstrate the characteristics of supply chain system in accordance with the proposed strategies. Then the strategies coupling with the supply chain models can be effortlessly comprehensible for the decision makers.

\section{Research results}

In this section, it presents the results from research, which can be divided into three main sections. Section one illustrates the supply chain structure of Hua-It Market, including the costs involved in supply chain of Hua-It activities. In section two, the formulated strategies for Hua-It market to be used as a guide for aiming to a collection and distribution center of agricultural products, will be introduced. And in last section, the supply chain models which are relevant and consistent to the strategies in section two will be proposed. Discussion in details of each section can be found in the following. 


\subsection{Supply chain structure}

To understand the overview of Hua-It market, the necessity to prepare supply chain structure is very crucial. Supply chain structure of Hua-It Market is illustrated in Figure 2. From this figure, it can be seen all the members involved, also logistics activities and nonlogistics activities occurred, in supply chain of Hua-It Market. In addition, logistics costs of each activity in supply chain were investigated in order to quantify the total systemwide cost of supply chain. Also it is illustrated the all costs relevant to logistics activities and nonlogistics activities in Figure 3.

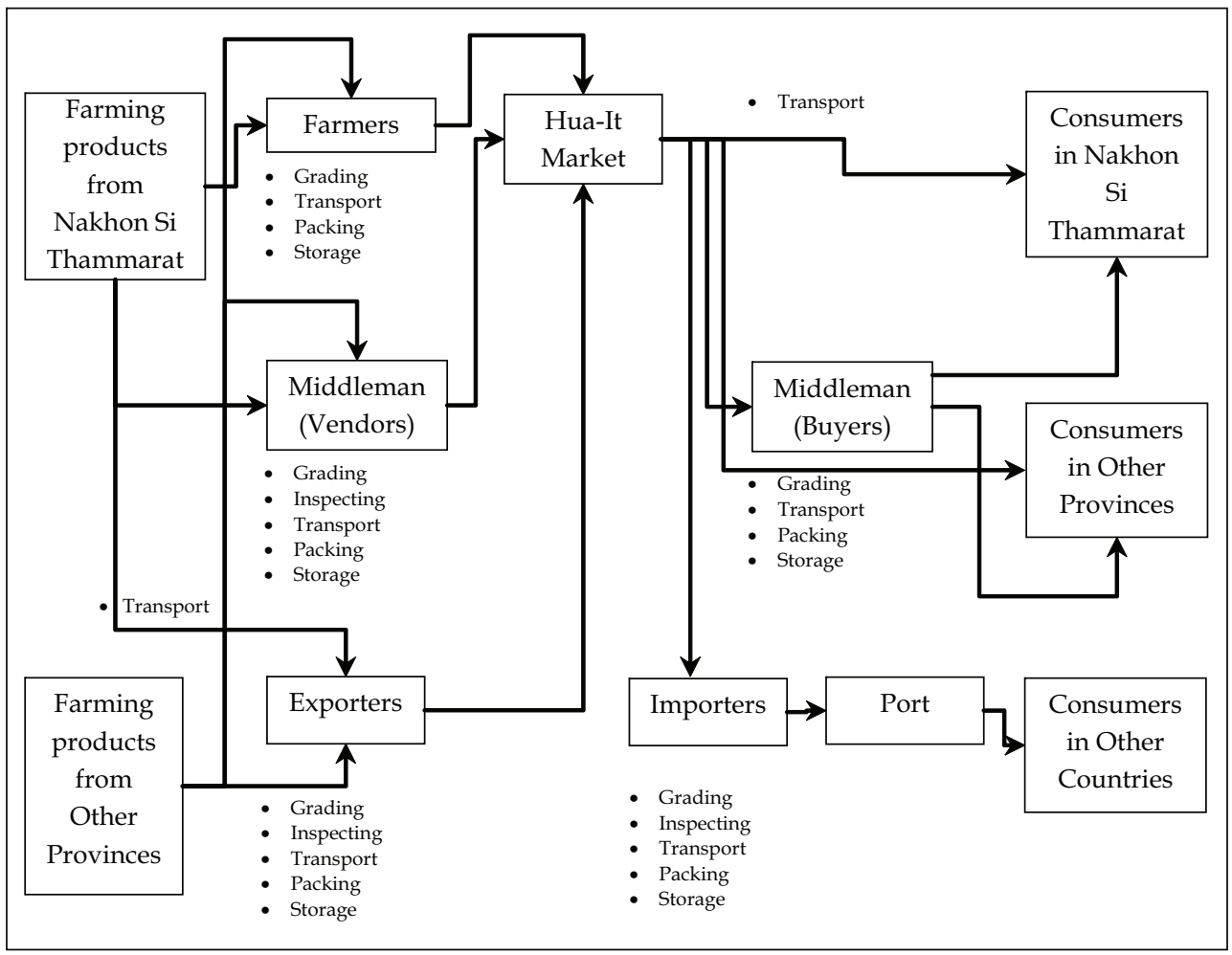

Fig. 2. Supply Chain Structure of Hua-It Market

From Figure 2, members in Hua-It supply chain can be divided into two main clusters, which are vendors and buyers. Furthermore, vendor cluster can also be categorized as farmer, middleman, and exporter. And buyer cluster, they are classified to be consumer, middleman, and importer. As well as, it can be notified that upstream of Hua-It Market starts off from two sources. One is from inside the Nakhon Si Thammarat and another is from other provinces where are outside. About eighty percent of products are from outside Nakhon Si Thammarat province. Before products are transported to Hua-It, they are transshipped through farmers, middleman (vendors), or exporters. For majority group of vendors of Hua-It, they are middleman, followed by exporter, and farmer, respectively. And from Hua-It, products are transshipped through middleman (buyers) or importers, to 
downstream of supply chain, who are consumers in Nakhon Si Thammarat, other provinces, or other countries. Nevertheless, there also is direct linkage from Hua-It to consumers in Nakhon Si Thammarat, without middleman. As well as, majority group of buyers of Hua-It, they are middleman, followed by consumer, and importer, respectively. Destinations of products mainly are in the southern of Thailand.

Also logistics activities, such transportation, packing, storage, and non-logistics activities, such grading, inspecting, at each stage of each member of supply chain are illustrated. These activities are contributing to the total systemwide cost in the following Figure 3.

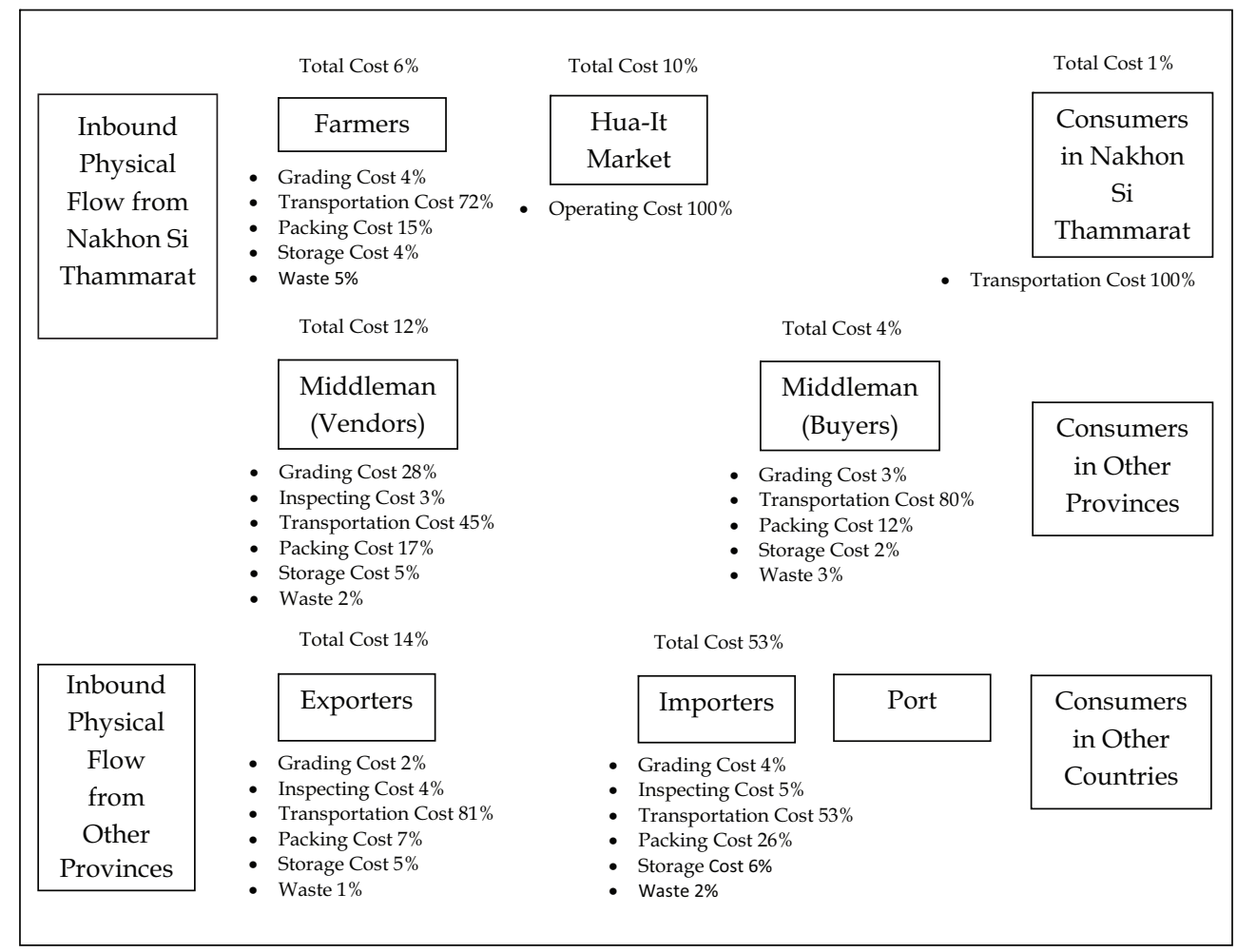

Fig. 3. Total Systemwide Cost of Hua-It Market Supply Chain

From Figure 3, it can be seen different types of costs involved in total systemwide cost of Hua-It supply chain. These costs are categorized as following activity based costing concept. When considering in details, it found out that the greatest percentage of costs of vendors, no matter who they are farmer, middleman, or exporter, is from transportation cost. Since most Hua-It's products are from out of Nakhon Si Thammarat Province and there is no collaboration among members in supply chain. Also the same characteristic for the buyer side, the transportation cost still is a great part of the total systemwide cost of supply chain. Since most products have been sold to nearby provinces where are not far from Hua-It, but transportation activities have not been collaborated thus it made the transportation cost is outstandingly high. 


\subsection{Strategies formulation}

In this section, it presents the strategy formulation for Hua-It which the data used were from three main sources, which are primary data from field survey, primary data from brainstorming, and secondary data from government agencies. The formulating strategy process was previously explained in section 3.4. Illustrations of calculation of weighted scores can be represented in the following Table 3.

\begin{tabular}{|c|c|c|c|}
\hline Internal Strategic Factors & Weight & Rating & $\begin{array}{l}\text { Weighted } \\
\text { Scores }\end{array}$ \\
\hline \multicolumn{4}{|l|}{ Strengths (S) } \\
\hline $\begin{array}{l}\text { 1. Hua-It is widely known for its vendors and } \\
\text { buyers who trade in market for a long time. }\end{array}$ & 0.0850 & 4.2400 & 0.3604 \\
\hline $\begin{array}{l}\text { 2. Hua-It is a unique symbol of Nakhon } \mathrm{Si} \\
\text { Thammarat. }\end{array}$ & 0.0950 & 3.6000 & 0.3420 \\
\hline $\begin{array}{l}\text { 3. Hua-It has the advantage in location since it is } \\
\text { located on a main road to the city. }\end{array}$ & 0.0858 & 3.6000 & 0.3089 \\
\hline $\begin{array}{l}\text { 4. Vendors and buyers in market have strong } \\
\text { relationship with mutual dependence like a large } \\
\text { family. }\end{array}$ & 0.0700 & 3.5000 & 0.2450 \\
\hline $\begin{array}{l}\text { 5. There are varieties of products according to the } \\
\text { requirements of consumers. }\end{array}$ & 0.0408 & 3.8400 & 0.1567 \\
\hline
\end{tabular}

Table 3. Example of Calculation of Weighted Scores

From Table 3, it is illustration of calculating of weighted scores for the strengths. The same procedure was repeated for $\mathrm{W}, \mathrm{O}$, and $\mathrm{T}$. Then all of them were selected from weighted scores to match up in TOWS Matrix Diagram. Afterward the results from matching in TOWS are strategies which are various perspectives such SO, WO, ST, and WT strategy type. The idea behind each type of strategy can be summarized as follows. SO strategy type will figure an approach for the operation by using the organization strengths, which are internal factors to take advantage from the opportunities, which are external factors. WO strategy type will improve the weaknesses in the organization by taking advantage from the opportunities. ST strategy type will use the strengths of the organization to avoid or lessen the impacts occurred from the threats from external factors. And WT strategy type is defensive tactics aiming to minimize the organization weaknesses and to avoid the threats from outside. Examples of SO, WO, ST, and WT strategy type can be illustrated Table 4 below.

Finally from different types of strategies will be blended as one for Hua-It. The following Table 5 illustrates the strategies for Hua-It Market. After obtaining the strategies, then each strategy was developed in the components, including objectives, indicators, targets, action plans, and departments or sectors who are responsible for or involved in each strategy. 


\begin{tabular}{|c|l|}
\hline $\begin{array}{c}\text { Strategy } \\
\text { Type }\end{array}$ & \multicolumn{1}{c|}{ Strategy } \\
\hline SO & Finding business alliances \\
\hline SO & Encouraging and developing integration \\
\hline WO & Increasing area utilization to accommodate future development \\
\hline WO & $\begin{array}{l}\text { Preparing standardization in organization both technical and management } \\
\text { aspects }\end{array}$ \\
\hline ST & Strengthening of the agricultural sector \\
\hline ST & Being a leader in product variety \\
\hline WT & Structuring the organization systematically \\
\hline WT & Developing organization information system \\
\hline
\end{tabular}

Table 4. Example of Strategies of Each Type

\begin{tabular}{|c|l|}
\hline No. & \multicolumn{1}{|c|}{ Strategy } \\
\hline 1 & $\begin{array}{l}\text { Aiming to be the Agricultural Quality Grading Center (AGQC) for agricultural } \\
\text { products }\end{array}$ \\
\hline 2 & $\begin{array}{l}\text { Building collaboration with all relevant members throughout Hua-It supply } \\
\text { chain in order to optimize the efficiency of agricultural management }\end{array}$ \\
\hline 3 & $\begin{array}{l}\text { Encouraging and developing of consolidation to focus on decreasing } \\
\text { transportation cost }\end{array}$ \\
\hline 4 & $\begin{array}{l}\text { Developing of Hua-It Market's infrastructure for supporting the growth in } \\
\text { future }\end{array}$ \\
\hline 5 & Encouraging and developing of export system \\
\hline 6 & $\begin{array}{l}\text { Developing of information system to link all relevant members throughout Hua- } \\
\text { It supply chain }\end{array}$ \\
\hline
\end{tabular}

Table 5. Strategies of Hua-It Market

From Table 5, let discuss some of strategies in details. Such in strategy no. 1, it gives the direction for Hua-It to aim to be AGQC, which the main functions are grading the product quality, packaging, storage, preserving quality during transportation, testing for plant diseases and insects, and testing for contaminants and toxic residues. The facts that found out from field survey are reference site market allocated the importance to grading product quality and testing for contaminants and toxic residues. At the reference market, there is agreement between the vendor and the market about grading product before shipping to market. In addition, at the reference market, it has its own laboratory that it will take products sampling from vendors and test for contaminants and toxic residues. While at Hua-It, these testing activities are outsourced to third party service provider. This can make high difference in term of costs. Thus if Hua-It aims to be a collection and distribution center, it cannot avoid these activities with any reason.

Strategy no.2 recommends Hua-It supply chain has to encourage the collaboration among members because it can improve the efficiency of agricultural management. The reason 
behind this strategy can be pointed out from survey. At reference market, the vendor, especially farmers, have banded together to sell to the market. Such the farmers who are from the same district will gather in the same car. This is simply the example of collaboration since this action is the main concept in logistics and supply chain management. Thus it can be imagined if this strategy can be accomplished, Hua-It supply chain can deliver more value with lower cost, which means high efficiency. Teaming up with strategy no.6, collaboration will not be completed unless there are information systems. Since information systems are the driver, which can increase the efficiency while can increase supply chain responsiveness at the same time.

Strategy no. 3 focuses on decreasing transportation cost. It is very obvious in Figure 3 that transportation costs of Hua-it supply chain, either incoming flows or outgoing flows are relatively high among other activities in the same supply chain. Furthermore, when compared with the reference market, Hua-It transportation costs also higher. The reasons from the fact are that transportation activities in Hua-it, either inbound or outbound hardly do together. Especially the middleman who is buyers, it occurs. Even the destinations of Hua-It's product are in the south, which are not far from Hua-It. Yet the transportation without consolidation can severely increase the cost. Thus in this strategy absolutely recommend Hua-It should encourage the consolidation, and the result from achieving this strategy will reveal in the next section.

\subsection{Supply chain model}

Supply chain models in this research have been developed with the purpose of linkage to the strategies in order to convey the ideas behind of these strategies, which are abstract to concrete. In addition, models can be used to measure performance of the market as a collection and distribution of agricultural products. The models were developed from quantitative data collected in a systematic method. There are three models represented in this section. First model is gravity location model relevant to the first strategy, which is aiming to be the center for the classification quality of agricultural products. Second model is hub and spokes model with cost related to third strategy. And the last model is about generalized network model with the objective of minimization total systemwide cost of supply chain.

\subsubsection{Gravity location model}

Gravity location model is a model that point to the coordinates or location for establishing the facility, where guarantee the minimization of transportation cost from sources of farming products to Hua-It and from Hua-It to consumers. This model is applied in order to ascertain that the current location of Hua-It Market is proper for being the collection and distribution center. Since Hua-It has been found since 1986, thus relocation of market is quite impossible. Therefore the gravity location model has been adopted to confirm its potential. The objective function of gravity location model and the optimum solution can be illustrated in equation (1), (2), and (3), respectively.

$$
\text { Min } T C=\sum_{n=1}^{k} d_{n} D_{n} F_{n}
$$




$$
\begin{gathered}
x^{\prime}=\frac{\sum_{n=1}^{k} \frac{D_{n} F_{n} x_{n}}{d_{n}}}{\sum_{n=1}^{k} \frac{D_{n} F_{n}}{d_{n}}} \\
y^{\prime}=\frac{\sum_{n=1}^{k} \frac{D_{n} F_{n} y_{n}}{d_{n}}}{\sum_{n=1}^{k} \frac{D_{n} F_{n}}{d_{n}}}
\end{gathered}
$$

where $T C=$ total transportation cost,

$d_{n}=\sqrt{\left(x-x_{n}\right)^{2}+\left(y-y_{n}\right)^{2}}$ (distance to location $n$ )

$D_{n}=$ quantity to be shipped between Hua-It and source or consumer $n$,

$F_{n}=$ cost of transportation one kilogram of farming product for one kilometer between Hua-It and either source or consumer $n$,

$x_{n}, y_{n}=$ coordinate location of either a source of products or consumer $n$, $x^{\prime}, y^{\prime}=$ optimum facility location.

Result from the gravity location model is indicated that the optimum location should be located at the coordinate $\left(x^{\prime}=590.06, y^{\prime}=960.80\right)$, where is Tambon Ka Roa, Amphur Nob Pi Tam, Nakhon Si Thammarat Province, which is farther than the current location of Hua-It about 30-35 kilometers, as shown in Figure 4.

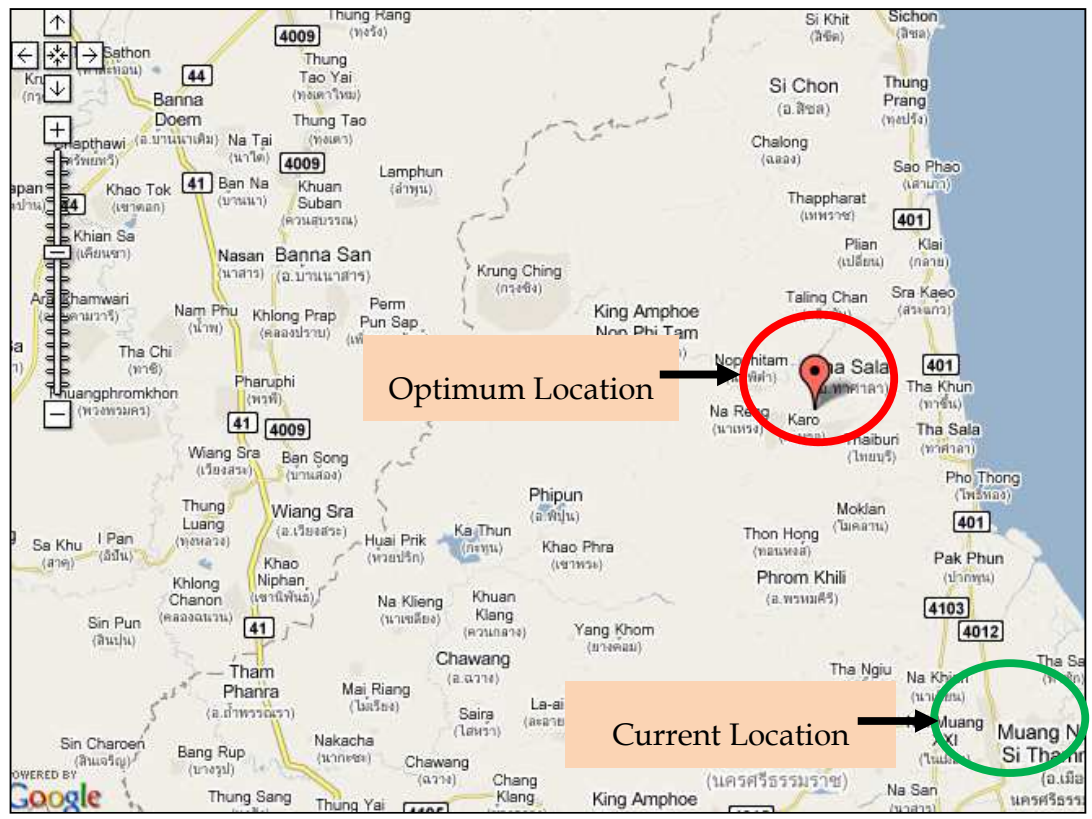

Fig. 4. Optimum Location from Gravity Location Model

(Source: maps.google.co.th) 
Total transportation cost incurred if Hua-It is located at the optimum location is $16,173,363$ baht/month, while if it is located at the current location, the cost of transportation is $16,245,283 \mathrm{baht} / \mathrm{month}$. It is found that the transportation cost decreases $71,920 \mathrm{baht} / \mathrm{month}$ or 0.44 percent. From this result, it can be notified that the difference of transportation cost between optimum location and current location only 0.44 percent which can be considered not significantly different. This result can confirm to the potential of Hua-It's current location that it is suitable for locating the collection and distribution center for the southern of Thailand. In addition, in the past, at its current location, it was a gas station and nearby the main road through the city. It is also a meeting point of vendors who brought farming products to sell in the city. Sometimes, they also traded to each other. That's the market activities happened. So this can prove the wisdom of the founder of Hua-It market in choosing the right location.

\subsubsection{Hub and Spokes model with cost}

Hub and spokes model with cost is a model that represents the minimum of total cost in establishing the collection points for incoming products and the distribution points for outgoing products. In this model, two main components of costs were considered, which are transportation cost and fixed cost of establishing collection or distribution points. This model is applied in order to illustrate the idea behind the third strategy that is promoting and developing of consolidation to focus on decreasing transportation cost. The objective function and the constraints of hub and spoke model can be illustrated in equation (4), (5), (6), (7) and (8), respectively.

$$
\begin{gathered}
\text { Min } T C=\sum_{i=1}^{m} \sum_{j=1}^{n} V_{i} R_{i} d_{i j} x_{i j}+\sum_{j=1}^{n} F_{j} y_{j} \\
\sum_{j=1}^{n} x_{i j}=1 \quad \text { for all } i \\
x_{i j} \leq y_{j} \\
\sum_{j=1}^{n} y_{j}=p \\
x_{i j}, y_{j}=\{0,1\}
\end{gathered}
$$

where $T C=$ total cost of establishing collection points or distribution points,

$F_{j}=$ fixed cost of establishing either a collection point or a distribution point,

$i=$ node of either a source of products or a consumer,

$j=$ node of either a collection point or a distribution point,

$V_{i}=$ quantity of goods to be transported either from a source of products or to a consumer,

$R_{i}=$ transportation rate either from a source of products or to a consumer,

$d_{i j}=$ distance between a source of products and a collection point or between a distribution point and a consumer,

$p=$ numbers of collection points or distribution points, 
$x_{i j}=1$ when there's a shipment from a source to a collection point or from a distribution point to a consumer, otherwise $x_{i j}=0$,

$y_{j}=1$ when a collection point or a distribution point is established at node $j$, otherwise $y_{j}=0$.

Interpretation of model can be clearly made in the following. Equation (4) denotes the total cost in establishing collection points or distribution points, comprising of the variable cost and the fixed cost. The variable cost mainly in this model is transportation cost, while the fixed cost can be regarded as investment cost of setting up that collection point or distribution point. Equation (5) denotes either from a source $i^{\text {th }}$ of product must be shipped to single collection point $j^{\text {th }}$, only, or a consumer $i^{\text {th }}$ in market must be received from single distribution point $j^{\text {th }}$, only. Equation (6) denotes either from a source $i^{\text {th }}$ of product must be shipped to a collection point $j^{\text {th }}$, which is open, only, or a consumer $i^{\text {th }}$ in market must be received from a distribution point $j^{\text {th }}$, which is open, only. Equation (7) denotes numbers of collection points or distribution points to be open. And equation (8) indicates that all decision variables are binary integer number.

Solutions from this model can be categorized into two sets, which are establishing collections points for incoming products and establishing distribution points for outgoing products. Detail of the solution set from establishing collection points is expressed as follows. A criterion for choosing the place to launch a collection point is the distance from Hua-It Market. In Nakhon Si Thammarat Province, it is assigned one collection point within radius of 50 kilometers. But there will be one collection point within radius of 200 kilometers for other areas, which are outside Nakhon Si Thammarat. From this criterion, there are 10 collection points, where can be launched. And then comparison for the right amount of collection points that should be opened is made through the mathematical model.

From Figure 5, it can be said that number of collection points that will minimize total cost of establishment are two points and the total cost will be 11,289,960 baht/month. While if there are no collection points, the total cost will be 18,774,430 baht/month. Thus total cost will be cut down by $7,484,470 \mathrm{baht} / \mathrm{month}$ or 39.87 percentages. The solution from hub and spokes model recommended that two collection points should be launched in two districts, where one is in Nakhon Si Thammarat, located in the southern Thailand, and another is in Ratchaburi, located in the central Thailand. Each point will be a collection center of incoming products which are from various districts. And when considering it in detail, the collection point in Nakhon Si Thammarat will receive incoming products from the sources where are widely in the southern area. And the collection point in Ratchaburi will collect the products, which are from the northern, northeastern, eastern, and central of Thailand.

And detail of the solution set from establishing distribution points is discussed in the following. A criterion for choosing the place to launch a distribution point is also the distance from Hua-It Market. In Nakhon Si Thammarat Province, it is assigned one distribution point within radius of 50 kilometers. But there will be one distribution point for every 100 kilometers radius from Hua-It for other areas, which are outside Nakhon Si Thammarat. Likewise the case of collection point, there are 6 distribution points, where can be launched from this criterion. And then comparison for the right amount of distribution points that should be opened is proved by the mathematical model. 


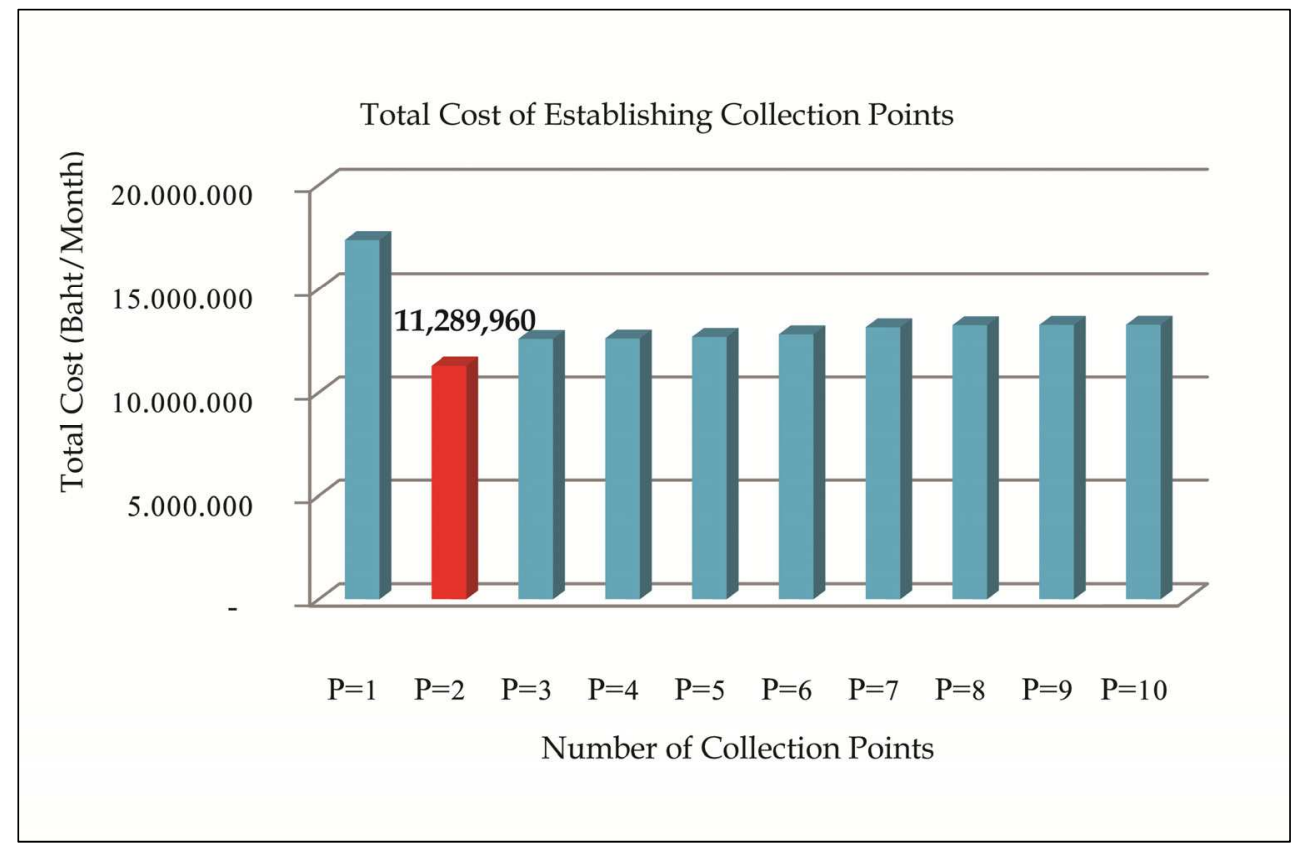

Fig. 5. Total Cost Comparison among Different Number of Collection Points

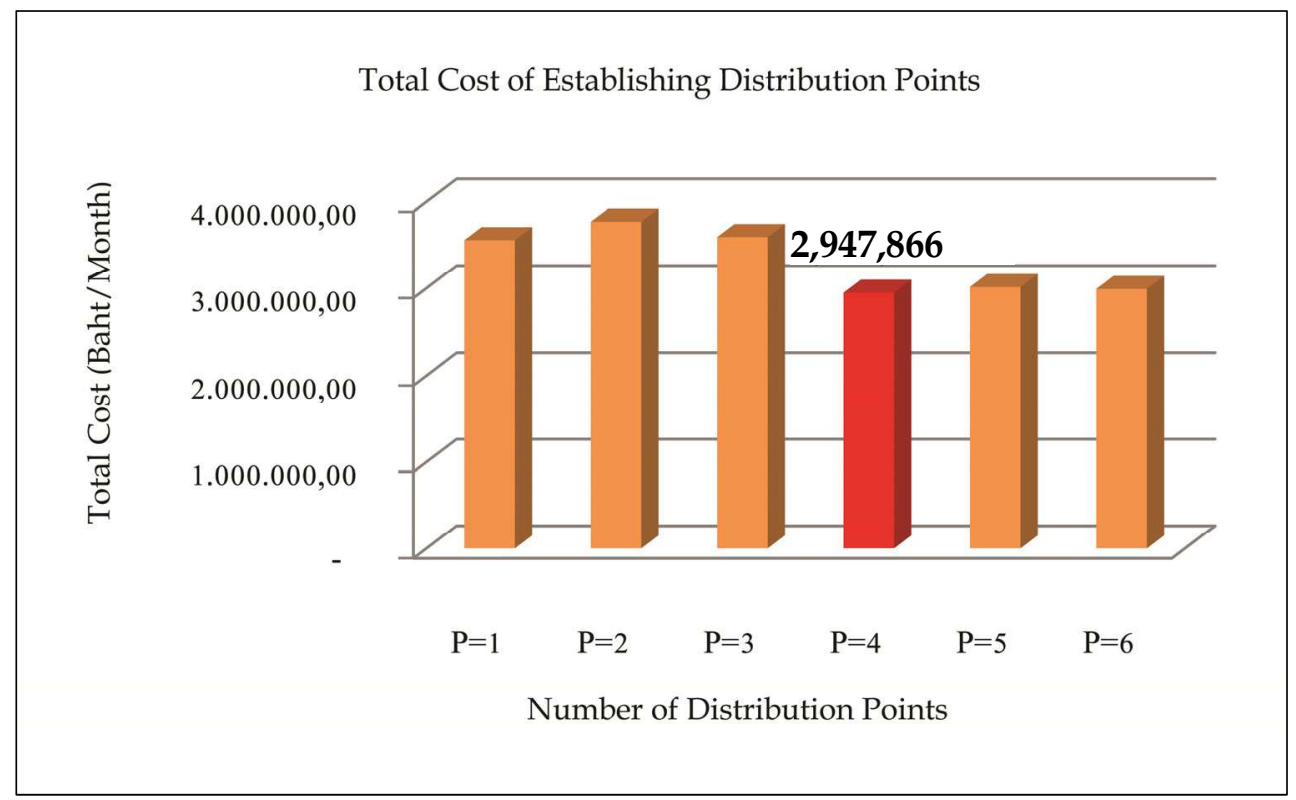

Fig. 6. Total Cost Comparison among Different Number of Distribution Points 
From Figure 6, it can be declared that numbers of distribution points that will minimize total cost of establishment are four points and the total cost will be 2,947,866 baht/month. While if there are no distribution points, the total cost will be 5,520,335 baht/month. Thus total cost will be cut down by 2,572,469 baht/month or 46.60 percentages. The solution from hub and spokes model recommended that four distribution points should be launched in four districts, where are in Nakhon Si Thammarat, Phattalung, Phang-Nga, and Yala, all located in the southern Thailand. Each point should be launched a distribution center of outgoing products to consumers who are widely spread in numerous districts where all are in the southern Thailand.

In addition, when considering the whole inbound and outbound together by having collection points and distribution points, the transportation costs incurred is $14,237,826$ baht/month. While if there are no collection points and distribution points, the transportation costs will be $24,294,765 \mathrm{baht} /$ month. It means the transportation costs can be cut down by $10,056,939 \mathrm{baht} / \mathrm{month}$ or 41.40 percentages. The results from this model are indicated that promoting and developing of consolidation among inbound and outbound parties of Hua-It supply chain are required in order to decrease transportation cost which will effect to the total systemwide cost of supply chain.

\subsubsection{Generalized network model}

Generalized network model is a model that represents the physical flow of product from upstream to downstream, with the objective of minimizing the total systemwide cost of supply chain. In this research, fifteen products accounted for 80 percent of the total product which have the highest trading volume, were studied. These products include vegetables, which are cabbage, pumpkin, cassava, cucumber, gourd, chili, lemon, and fruits which are watermelon, mango, orange, jackfruit, pineapple, pomelo, and banana. This model will reflect the total systemwide cost of each product flowing from sources to consumers in HuaIt supply chain. Components of costs that taken into this model, include production cost, grading cost, packaging cost, inspection cost, transportation cost, storage cost, and cost from product waste. This model is applied in this research in order to support the second strategy that is building collaboration with all relevant members throughout Hua-It supply chain in order to optimize the efficiency of agricultural management. Because the efficiency can be measured by output divided by input, which is cost, thus recognizing the total systemwide cost will be very informative in viewpoint of agricultural management.

Flow structures of each product, mentioned previously, in Hua-It Market can be categorized into three patterns. First structure is products have sourced from other districts, where are not in the south. Second is products have sourced in the south, only. And third structure is products have sourced from both in the south and not in the south. Flow diagrams relevant to all three structures can be illustrated in Figure 7, Figure 8, and Figure 9, respectively.

In this manuscript will represent the network model of the third flow structure as follows. The formulated objective function and the constraints of the generalized network model can be illustrated in equation (9) - (16), respectively.

$$
\operatorname{Min} z=\sum_{i=1}^{n} \sum_{j=1}^{o} c_{i j} x_{i j}+\sum_{i=1}^{n} \sum_{k=1}^{p} c_{i k} x_{i k}+\sum_{j=1}^{o} \sum_{k=1}^{p} c_{j k} x_{j k}+\sum_{k=1}^{p} \sum_{l=1}^{q} c_{k l} x_{k l}
$$




$$
\begin{gathered}
\sum_{j=1}^{o} x_{i j} \leq S_{i} \quad \text { for } i=1,2,3, \ldots, n \\
\sum_{i=1}^{n} x_{i j}-\sum_{k=1}^{p} x_{j k} \geq 0 \text { for } j=1,2,3, \ldots, o \\
\sum_{k=1}^{p} x_{j k} \leq T_{j} \quad \text { for } j=1,2,3, \ldots, o \\
\left(\sum_{i=1}^{n} x_{i k}+\sum_{j=1}^{o} x_{j k}\right)-\sum_{l=1}^{q} x_{k l} \geq 0 \quad \text { for } \quad k=1,2,3, \ldots, p \\
\sum_{l=1}^{q} x_{k l} \leq U_{k} \quad \text { for } k=1,2,3, \ldots, p \\
\sum_{k=1}^{p} x_{k l}=D_{l} \quad \text { for } l=1,2,3, \ldots, q \\
x_{i j}, x_{i k}, x_{j k}, x_{k l} \geq 0
\end{gathered}
$$

where $i=$ node (district) where is the source of product, starting from 1 to $n$,

$j=$ node (district) where is the collection of product, starting from 1 to $o$,

$k=$ node (district) where is the location of market, starting from 1 to $p$, generally, but in this case $k=1$ denoting Hua-It Market,

$l=$ node (district) where is the consumer of product, starting from 1 to $q$,

$S_{i}=$ supply capacity at source (district) $i$,

$T_{j}=$ capacity at collection node (district) $j$,

$U_{k}=$ capacity at Hua-It Market,

$D_{l}=$ demand at consumer node (district) $l$,

$x_{i j}=$ quantity of product flows from source $i$ to collection $j$,

$x_{i k}=$ quantity of product flows from source $i$ to Hua-It Market,

$x_{j k}=$ quantity of product flows from collection $j$ to Hua-It Market,

$x_{k l}=$ quantity of product flows from Hua-It Market to consumer $l$,

$c_{i j}=$ total cost per unit of product flowing from source $i$ to collection $j$,

$c_{i k}=$ total cost per unit of product flowing from source $i$ to Hua-It Market,

$c_{j k}=$ total cost per unit of product flowing from collection $j$ to Hua-It Market,

$c_{k l}=$ total cost per unit of product flowing from Hua-It Market to consumer $l$.

Interpretation of model can be clarified as follows. Equation (9) denotes objective function with aiming to minimize the total systemwide cost of Hua-It supply chain, starting from sources of products $i$, collection $j$, Hua-It market, and finishing at consumers $l$. Equation (10) denotes quantity of product flows from source $i$ to collection $j$ shall not exceed supply capacity at source (district) $i$. Equation (11) denotes quantity of product flows from collection $j$ to Hua-It Market must not exceed the amount received from quantity of product flows from source $i$ to collection $j$. Equation (12) denotes quantity of product 


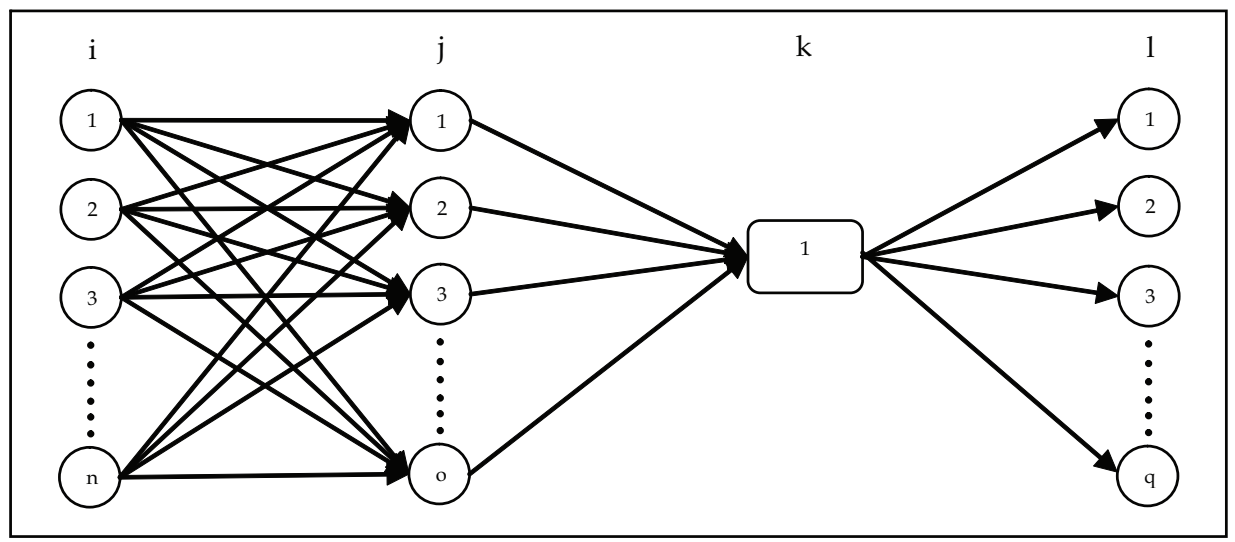

Fig. 7. Flow Structure Pattern I

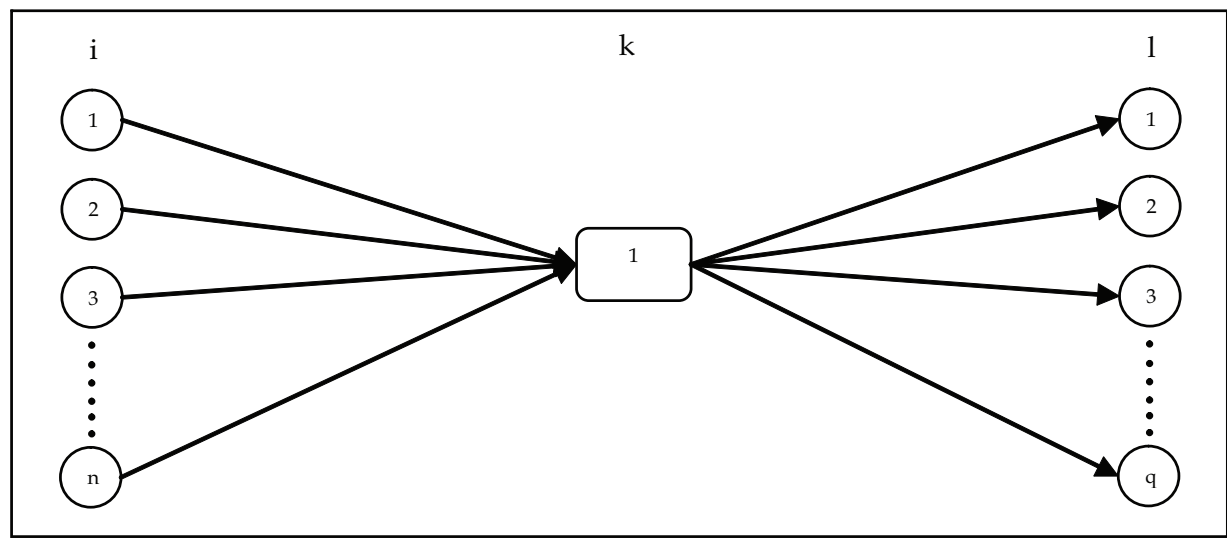

Fig. 8. Flow Structure Pattern II

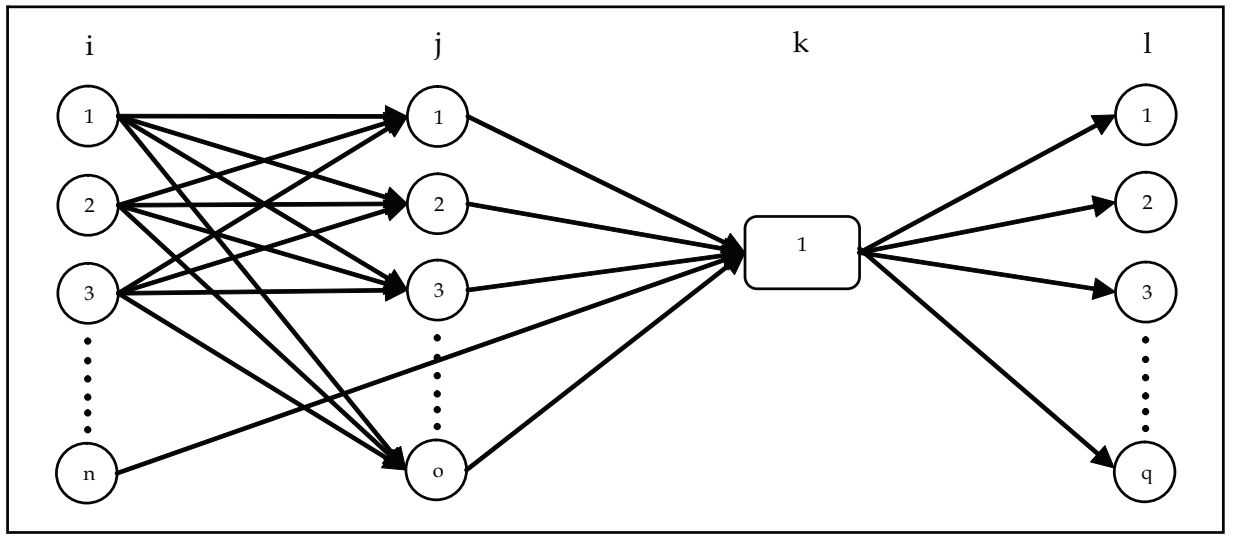

Fig. 9. Flow Structure Pattern III 
flows from collection $j$ to Hua-It Market shall not exceed capacity at collection node (district) $j$. Equation (13) denotes quantity of product flows from Hua-It Market to consumer $l$ must not exceed the amount received from quantity of product flows from source $i$ plus quantity of product flows from collection $j$. Equation (14) denotes quantity of product flows from Hua-It Market to consumer $l$ shall not exceed capacity of Hua-It Market. Equation (15) denotes quantity of product flows from Hua-It Market to consumer $l$ must be equal demand at consumer node (district) $l$. And equation (16) indicates that all decision variables are real number that greater than zero.

Results obtained from the generalized network model are the total systemwide cost of each product and quantity flows between node to node in Hua-It supply chain. Illustration of result can be demonstrated in the following figure.

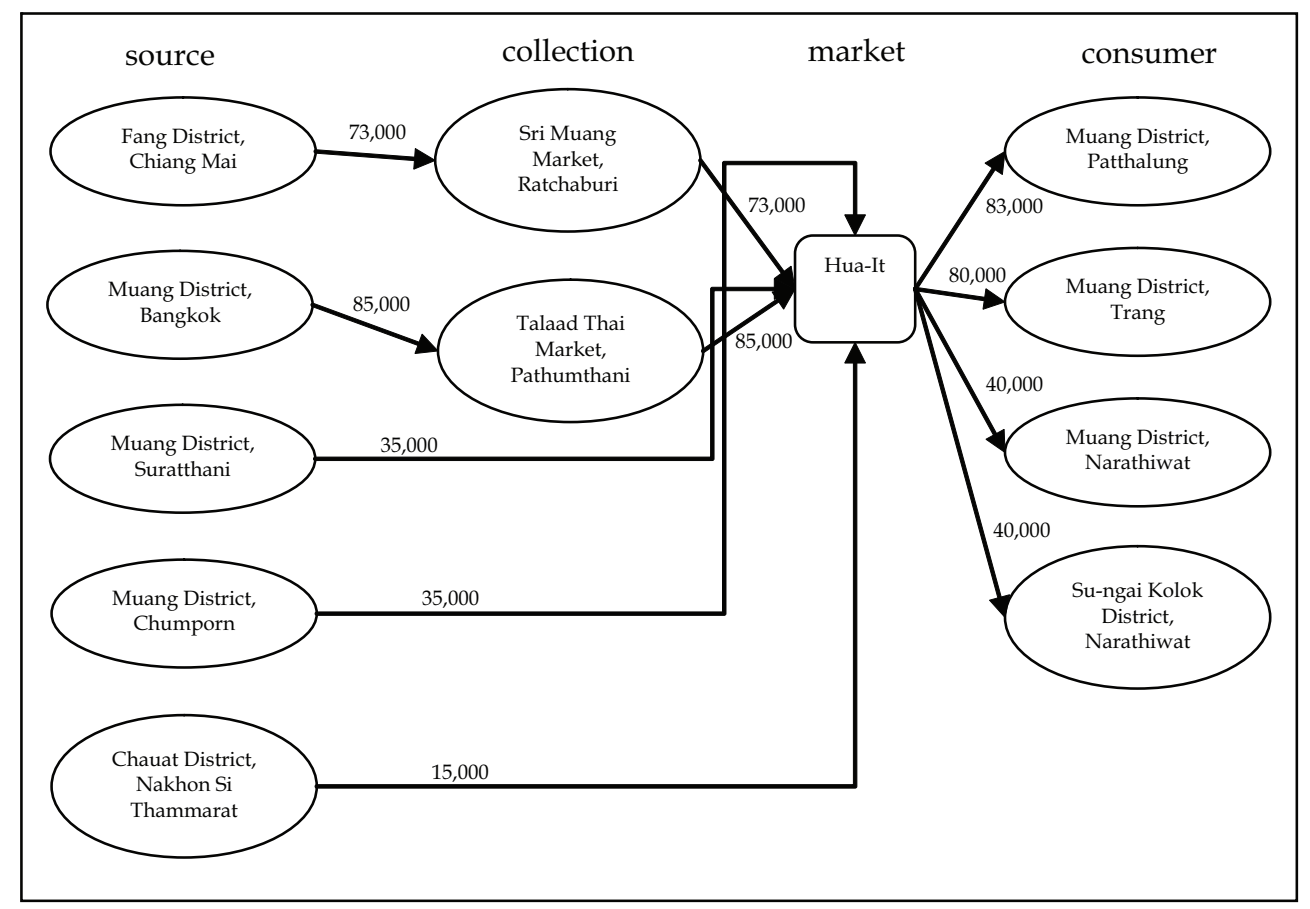

Fig. 10. Flow Structure of Orange, unit is kilograms/month

From Figure 10, the model searches through the supply chain network and provide the optimal flow from one node to another node. It can be seen the flow quantities of product from upstream to downstream in Hua-It supply chain. Costs incurred in this system include production cost, grading cost, packaging cost, inspection cost, transportation cost, storage cost, and cost from product waste. And the total systemwide cost of this product is $1,253,720$ baht/month. Absolutely by modeling the supply chain of all fifteen products, it can be identified the total costs of each product, also flow quantities. Thus this model will be served as a decision making tool in selecting and matching the source of the products and the location of markets with the guarantee of minimizing total systemwide cost. 


\section{Conclusion and future research}

In this research was focused on a potentiality study of Hua-It Market at Nakhon Si Thammarat Province, located in the south of Thailand. It intended to investigate whether or not Hua-It Market has potential enough to be a collection and distribution center for the southern Thailand along the requirements of Department of Internal Trade such being an "Agricultural Quality Grading Center (AGQC)", promoting collaboration among members in Hua-It supply chain, or reducing logistics costs along supply chain. Underlying research concept was gap analysis along logistics and supply chain management viewpoint. It aimed to clarify the relationships of processes in Hua-It supply chain, comprising of logistics activities and non-logistics activities, also cost incurred in the supply chain. It is following that collected data were exploited in the strategy development for Hua-It aiming to an agricultural collection and distribution center. Finally, supply chain modeling was carried out. These developed models supported the preparation of strategies and the analysis of supply chain performance.

The results of the research were the Hua-It's strategies which were evaluated under logistics and supply chain management viewpoint through the developed supply chain models. Each strategy clearly specified objective, indicators, targets, and action plan associated with the stakeholders. Since some strategies are required to demonstrate what actual performance will happen if the strategy is implemented? Thus the models can demonstrate the effect that is expected to turn out. The models applied and developed in the research were gravity location model, hub and spoke model with cost, and generalized network model. Each model was focused on logistics cost components, especially transportation cost which had high contribution to total systemwide cost of supply chain. Costs such production cost, grading cost, packaging cost, inspection cost, storage cost, and cost from product waste also integrated to the models, as well.

Key success factors for Hua-It Market in aiming to be a collection and distribution center for the southern Thailand obtained from this research can be stated as follows. (1) The development of market to be an agricultural quality grading center, which is responsible for grading the product quality, packaging, storage, preserving quality during transportation, testing for plant diseases and insects, and testing for contaminants and toxic residues. (2) The encouragement of collaboration among vendors and buyers for trading in market. (3) The improvement of market's infrastructures. (4) The encouragement and development of exporting system to Singapore, Malaysia, Indonesia, and the Middle East countries. (5) The operations in market with the minimum total systemwide cost. (6) The improvement of quality and cultivation standards of fruits and vegetables so that products can satisfy market needs and consumers tastes. (7) The founding of service centers for facilitating farmers operations. (8) The encouragement of farmers to abide by Good Agricultural Practice (GAP).

To fulfill the transformation of Hua-It Market to a collection and distribution center for the southern Thailand, it counts on the competency of market executives to manage the operations efficiently. Nevertheless, it also relies on the cooperation among related agencies, both public and private sectors. Particularly, the public sectors must perform as coordinators, urge, promote, and encourage as well so that the collaboration among Hua-It supply chain can take place, ultimately, in order to achieve the mission of a collection and distribution center for the south of Thailand. 
For future research is an extension from this study. Department of Internal trade, Ministry of Commerce wishes for launching distribution center for agricultural product in four regions of Thailand in order to strengthen the domestic trade system and alleviate the price fluctuation of agricultural product. The question such where are the optimum locations for each distribution center in each region? What is the capacity of each distribution center? How these four distribution centers can collaborate? Or which kind of products should flow from or to which distribution center, etc? This kind of problem constantly emerges in the supply chain management field and it challenges for supply chain practitioners, at all times.

\section{Acknowledgment}

This research project was fully supported by a grant from The Thailand Research Fund through Contract No. RDG5050032. In addition, the authors would like to thank Mr. Borirak Chusit, Office of Internal Trade, Nakhon Si Thammarat Province, Department of Internal Trade, Ministry of Commerce and executives of Hua-It market, for their excellent collaborations under this research project.

\section{References}

Beamon, B. M. (1998). Supply Chain Design and Analysis: Models and Methods. International Journal of Production Economics, Vol.55, No.3, (August 1998), pp. 281294, ISSN 0925-5273

Campbell, J. F. (1994). Integer Programming Formulations of Discrete Hub Location Problems. European Journal of Operational Research, Vol.72, No.2, (January 1994), pp. 387-405, ISSN 0377-2217

Campo, I. S. \& Beghin, J. C. (2006). Dairy Food Consumption, Supply, and Policy in Japan. Food Policy, Vol.31, No.3, (June 2006), pp. 228-237, ISSN 0306-9192

Cochran, J. K. \& Ramanujam, B. (2006). Carrier-mode Logistics Optimization of Inbound Supply Chains for Electronic Manufacturing. International Journal of Production Economics, Vol.103, No.2, (October 2006), pp. 826-840, ISSN 0925-5273

Fernie, J. \& Staines, H. (2001). Towards an Understanding of European Grocery Supply Chains. Journal of Retailing and Consumer Services, Vol.8, No.1, (January 2001), pp. 29-36, ISSN 0969-6989

Lertkrai, P. (2000). Structure and Dynamic of Crop Market: Hua-It Market, Nakhon Si Thammarat Province. Research Report (Undergraduate Level), Nakhon Si Thammarat Rajabhat University

Poorpongsakorn, N. (2005). An Analysis Study of Marketing Management System of Freshed Fruits and Processed Fruits in the East of Thailand. Research Report, Thailand Development Research Institute 


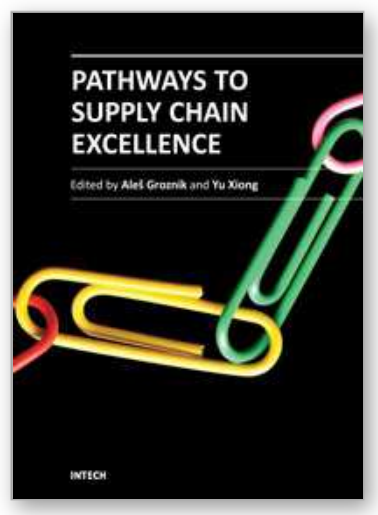

\author{
Pathways to Supply Chain Excellence \\ Edited by Dr. Ales Groznik
}

ISBN 978-953-51-0367-7

Hard cover, 208 pages

Publisher InTech

Published online 16, March, 2012

Published in print edition March, 2012

Over the last decade, supply chain management has advanced from the warehouse and logistics to strategic management. Integrating theory and practices of supply chain management, this book incorporates hands-on literature on selected topics of Value Creation, Supply Chain Management Optimization and MassCustomization. These topics represent key building blocks in management decisions and highlight the increasing importance of the supply chains supporting the global economy. The coverage focuses on how to build a competitive supply chain using viable management strategies, operational models, and information technology. It includes a core presentation on supply chain management, collaborative planning, advanced planning and budgeting system, risk management and new initiatives such as incorporating anthropometry into design of products.

\title{
How to reference
}

In order to correctly reference this scholarly work, feel free to copy and paste the following:

Sakesun Suthummanon, Pallapat Penjamras, Somboon Jaroenjiratrakul, Sopin Suddsa-oad and Nikorn Sirivongpaisal (2012). A Potential Study of HUA-IT Market Aiming as a Collection and Distribution Center of Agricultural Products in Southern of Thailand, Pathways to Supply Chain Excellence, Dr. Ales Groznik (Ed.), ISBN: 978-953-51-0367-7, InTech, Available from: http://www.intechopen.com/books/pathways-to-supplychain-excellence/a-potential-study-of-hua-it-market-as-a-collection-and-distribution-center-of-agriculturalproducts-

\section{INTECH}

open science | open minds

\section{InTech Europe}

University Campus STeP Ri

Slavka Krautzeka 83/A

51000 Rijeka, Croatia

Phone: +385 (51) 770447

Fax: +385 (51) 686166

www.intechopen.com

\section{InTech China}

Unit 405, Office Block, Hotel Equatorial Shanghai

No.65, Yan An Road (West), Shanghai, 200040, China

中国上海市延安西路65号上海国际贵都大饭店办公楼 405 单元

Phone: +86-21-62489820

Fax: $+86-21-62489821$ 
(C) 2012 The Author(s). Licensee IntechOpen. This is an open access article distributed under the terms of the Creative Commons Attribution 3.0 License, which permits unrestricted use, distribution, and reproduction in any medium, provided the original work is properly cited. 